Vol. 1, No. 1

2004

DOI : http://dx.doi.org/10.15728/bbr.2004.1.1.1

pp. 1-16

\title{
The Ohlson Model of Evaluation of Companies: Tutorial for Use ${ }^{i}$
}

\author{
César Medeiros Cupertino \\ University of Brasília
}

\author{
Paulo Roberto Barbosa Lustosa \\ University of Brasília
}

\begin{abstract}
The article analyzes the structuring and applicability of the Ohlson Model (MO). The methodology used considered: (i) exploratory research as to the objectives of the study; (ii) bibliographical research as to the procedures applied; and (iii) qualitative research as to the addressing of the problem. The review of the literature covered both the origin (discount of dividends, evaluation by the residual profit etc) and the underlying theory of the model. In relation to the internal consistency of the $\mathrm{MO}$, the structuring of the linear informational dynamics was discussed (DIL) and the formula of evaluation as well as the establishing of the entries demanded (parameters and variables). An example was also developed that illustrates the interaction between the coefficients, variables and parameters of the Ohlson modeling. The example permitted the exploration of fundamental concepts and premises for the operating of the Ohlson model, underlying the equations of the DIL (self-regressive models, parameters of persistence etc), to the behavior of the profits (persistence and ability to forecast), to the scenario of evaluation and to some aspects of the accounts model (role of the net worth etc). The study concluded that: (1) there is no consensus in the academic literature about the appropriate method of measuring the parameters of persistence; (2) there are propositions for perfecting the original conception of the MO by means of extensions to the model; (3) the Ohlson model propitiated a series of contributions in the academic literature about capital markets.
\end{abstract}

Key-words: evaluation of companies, Ohlson Model.

César Medeiros Cupertino

Doutor em Engenharia de Produção

Universidade Federal de Santa Catarina, UFSC

Adress: Av. Gov. Irineu Bornhausen, 4744,

Centro, 88025-201 - Florianopolis - SC-Brasil

Email: cupertino.cmc@gmail.com

Telephone: (48) 32816595
Paulo Roberto Barbosa Lustosa

Doutor em Controladoria e Contabilidade

Universidade de Brasilia UNB

Adress: Asa Norte - 70910900 - Brasilia - DF-

Brasil

Email:prblustosa@gmail.com

Telephone: (061) 3107089

\footnotetext{
${ }^{\mathrm{i}}$ This article weas presented at the 4th USP Congress of Contollership and Accounting.
} 


\section{INTRODUCTION}

valuation of companies is one of the principal demands in research about capital

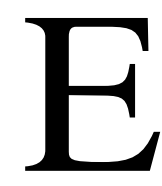
markets (KOTHARI, 2001). Bodie and Merton (2002) and Damodaran (1999) highlight that the ability of evaluating assets with precision is at the heart of the theory of finances because many personal and business decisions can be made by the selection of alternatives that maximize the value. Fernández (2001) states that the evaluation can be used for various purposes amongst which: to determine the initial price of an IPO (Initial Public Offering); to serve as a parameter of comparison of the shares negotiated in stock exchanges, to quantify the creation of value that is attributable to the executives of the company (and thus give them bonuses); to help in the strategic decision making (decision to continue in the business, to sell, expand, merge or buy other companies).

A series of relevant questions can apply in the task of evaluating an investment: market efficiency, forecasts of analysts and cost of opportunity are some of them. In some models there are attempts to capture the interaction of these questions in evaluation formulas, with methodological approaches that vary in degree of complexity ${ }^{\mathrm{ii}}$. As to this aspect, Ohlson (1995) presented a formulation derived from the classical conceptions that used accounts variables in the function of evaluation. The structuring was baptized Ohlson Model (MO) and had great impact in the academic research about capital markets.

Acquainted with the intense discussions about this model in foreign literature, the Ohlson model still is an incipient subject in Brazil (LOPES, 2001). Exceptions repose in some few works with predominantly quantitative focus and that in the majority of cases do not consider that which is the innovation proportioned by the model: the premise of the linear informational dynamics. In this sense the article makes an incursion into the Ohlson model with the intuit of proportioning better comprehension of that which it represents and of the way that the variables interact in the evaluation function.

The rest of the study is found organized as follows: section 2 offers the theoretical basis, section 3 describes the methodology applied, section 4 focuses on the Ohlson model (structuring and entries demanded); section 5 demonstrates the extensions to the model and section 6 concludes the work.

\section{THEORETICAL BASIS}

The theory of finances describes the value of the company in terms of expected future dividends (PENMAN; SOUGIANNIS, 1998), being the model of discount of dividends (MDD) the basic and theoretically correct approach of evaluation (PLENBORG, 2000). Its formal representation is given by:

$$
p_{t}=\sum_{\tau=1}^{\infty} R^{-\tau} E_{t}\left(\tilde{d}_{t+\tau}\right)
$$

where:

$p_{t}$ is the market value of the company on date $t$;

$\tilde{d}_{t+\tau}$ is assumed to represent the net dividends in $t+\tau$,

$R$ is the discount rate $r$ (rate free of risk) plus " 1 ", indicated as a constant;

\footnotetext{
${ }^{\text {ii }}$ One sees the existence of simple models (of the uni-varied way or random-walk) and sophisticated models (of the multi-varied type and self regressive processes of multiple order).
} 
$E_{t}$ means the operator of expectation based on the information available on this date $t$.

The formula focuses the problem of evaluation in the perspective of the investor: on buying a part of the net worth of the company, the investor expects to receive dividends referent to this portion. The value of the fraction that belongs to him must be equal to the present value of the flow of dividends (ANG; LIU, 1998). With this construction the MDD constitutes the traditional focus for evaluation of companies in the economic and finances literature (ANG; LIU, 1998), being used as foundations in the formulation of other models, as for example the evaluation by the residual profit (ALR). For Lo and Lys (2000), the ALR reposes on the simple hypothesis that the value of the company represents the present value of all future dividends.

The model of evaluation by the residual profit was largely ignored in specialized literature. Its reappearance constitutes a major contribution to modern accounting (LUNDHOLM, 1995). By the use of profits, accountable value of the PL and the relationship Clean Surplus, the MDD is re-written as a model of discount of accountable numbers. In its most far reaching form the model expresses the value of the company as the sum of its capital investments and the present value discounted from the residual profit of its future activities.. Thus,

$$
p_{t}=b_{t}+\sum_{\tau=1}^{\infty} R^{-\tau} E_{t}\left(x_{t+\tau}^{a}\right)
$$

where:

$b_{t}$ is assumed to represent the accountable value of the PL on date $t$;

$x_{t+\tau}^{a}$ denotes the residual profits in the period $t+\tau$.

Equation (2) shows that the value of the company can be divided into two parts: one accounts measure of capital invested - $b_{t}$ - and a measure of the value of the expected residual profits $-\sum_{\tau=1}^{\infty} R^{-\tau} E_{t}\left(x_{t+\tau}^{a}\right)$. This last parcel is defined as the present value of the flows of the future economic results still not incorporated into the net worth current accounting. If the firm obtains future results at the same rate as its desired remuneration of the capital (represented by the discount rate $r$ ), then the present value of the future residual profits will be zero. In other words, for the companies that do not create or destroy wealth, the variable of relevance for the evaluation will only be its accountable value of the net worth.

In turn, the residual profit of the period $t$ is defined as the amount that the firm gains in excess of the discount rate applied on the accountable value of the PL of the previous period ( $t$ - 1). The terminology was motivated by the concept that "normal" profit must be related to the "normal" return on capital invested at the start of the period, that is, the accountable value of the PL on the date " $t$-l" (OHLSON, 1995). In this way the "residual" profit is interpreted as the profit ${ }^{\mathrm{iii}}$ diminished from the charge on the use of capital.

$x_{t}^{a}=x_{t}-r\left(b_{t-1}\right)$

where $r$ is the discount rate and $x_{t}$ the accountable profit $(t-1, t)$.

\footnotetext{
${ }^{\mathrm{iii}}$ In this case the ample or far reaching profit (comprehensive income). 
As described, the concept imposed by equation (3) permits one to conclude that a positive value of residual profit indicates a lucrative period for the company in the measure in which the accountable rate of return exceeds the capital cost of the firm.

To derive ALR from the MDD, two additional premises are necessary (LO; LYS, 2000). The first refers to the adoption of an accounts system that satisfies the relationship Clean Surplus (Clean Surplus Relation - CSR). The CSR is a restriction in the relationship between accountable profits $(x)$, accountable value of the PL $(b)$ and net dividends $(d)$ in the period $t$ (Myers, 1999). Essentially, CSR is a condition imposed so that all the net worth variations transit through the result. Its mathematical notation is given by:

$$
b_{t}=b_{t-1}+x_{t}-d_{t}
$$

This representation of profits is a great advance over the previous constructions (LUNDHOLM, 1995). The formula ties profits and accountable value of the PL in the same equation and implies that the goodwill is equal to the present value of the expected future residual profits (OHLSON, 1995). A consequence of its adoption in ALR is the independence in relation to a specific accounting system. Given a flow of future dividends, the values of $b_{t}$ and of $x_{t}$ can be taken by any random numbers. The assertive is sustained in the fact that $b_{t}$ is updated according to equation (4) and the relationship of evaluation in equation (2) will take charge of producing the present value of the flow of dividends (DECHOW et al., 1999, p. 4).

The second premise to derive the ALR from the MDD is a condition of regularity that imposes that an accountable value of the PL increases at a lesser rate than $R$.

$$
R^{-\tau} E_{t}\left(b_{t+\tau}\right) \stackrel{\tau \rightarrow \infty}{\longrightarrow} 0
$$

The ALR model connects the evaluation of companies to observable accountable data apart from basing itself on simple mathematical constructions (LO, LYS, 2000). The study promoted by Ohlson (1995) characterizes a model of residual profit similar to the ALR. In spite of the original ALR anteceding the MO by many decades, Ohlson offered the possibility of repositioning the focus of the accounts research on evaluation of companies establishing a formal connection between the ALR and propositions provided by an additional structure denominated linear information dynamic (DIL).

\section{METHOLDOLOGY AND SOURCE OF DATA}

As to the objectives, the article classifies itself as exploratory research. Beuren (2003, p. 80) highlights that one seeks, with the exploratory study, "[...] to know the matter with greater depth, so as to make it clearer [...]" and adds: "[...] to explore a subject means to gather more knowledge [...], as well as to seek new dimensions up to then unknown." (BEUREN, 2003, p. 81). Pinsonneault and Kraemer (1993 apud HOPPEN et al., 1996) highlight that the exploratory research is an elucidative way to analyze new concepts. The study maintains such orientations: it addresses a subject still little explored in national literature and critically analyzes the model in its applicability and empirical testability.

As to the procedures, bibliographical research was used. Cervo and Bervian (1983) teach that the bibliographical research:

[...] explains a problem from the theoretical references published in documents. It can be done independently or as part of descriptive or 
experimental research. Both the cases seek to know and analyze the cultural or scientific contributions of the past, existent about a determined matter, theme or problem.

In bibliographical research all referential published serves as a source of consultation: articles from periodicals, magazines, books, theses etc (BEUREN, 2003). Given the scarce national literature existent about the Ohlson model, the research was essentially based on foreign publications, notably periodicals ${ }^{\text {iv }}$ and books. Additionally, a search was made on the world network of computers - Internet - involving key-words about the theme ${ }^{v}$.

As to the approach of the problem, the article classifies itself as qualitative research. Beuren (2003, p. 92) highlights that:

In the qualitative research deeper analyses are conceived in relation to the phenomenon that is being studied. The qualitative approach aims at highlighting characteristics not observed by means of a quantitative study, seeing the superficiality of the latter.

Van Maanen (1983 apud HOPPEN et al., 1996) teaches that the qualitative methodologies are constituted by a set of interpretative techniques. Hoppen et al. (1996) advocate that the qualitative research is complex for being based on words and not on numbers. Now Richardson (1999) highlights that the difference between qualitative and quantitative research is that the latter employs statistical instruments as the basis of the process of analysis of the problem whereas the other does not have this appeal.

\subsection{Structuring}

\section{THE OHLSON MODEL}

Considering the existent theory, Prof. James Ohlson saw the possibility of structuring a model of evaluation sustained by the relationship of clear profit (CSR), where accountable variables had an outstanding role. He orientated himself in the model of evaluation by the residual profit and established 3 premises: (i) the MDD determines the market value considering the neutrality to the risk; (ii) traditional accountancy that satisfies CSR is applied; (iii) the MO defines the stochastic behavior of $x_{t}^{a}$. In (i), the premise considers the use of the present value of the future dividends discounted jointly with the property of irrelevance of the dividends to define the share prices. Now in (ii), formula (4) guarantees the consistence of the determination of profit independently of the accounting system adopted.

For the stochastic behavior of $x_{t}^{a}$ some considerations are necessary. Ohlson (1995) and Lundholm (1995) emphasize that the empirical implications of the model critically depend on this last premise, related to the informational dynamics of the residual profits. Its function is to put restrictions in the Standard model of discount of dividends. Seen from an empirical perspective, the firm continues being evaluated by the MDD with the differential of the nature of the relationship between the current information and the discounted value of the

\footnotetext{
${ }^{\text {iv }}$ As to the periodicals, the research included the consultation, amongst others, of the following: Contemporary Accounting Research; Journal of Finance; The Accounting Review; Journal of Accounting, Auditing and Finance; Journal of Accounting and Economics; Journal of Accounting Research; Journal of Business.

${ }^{\mathrm{v}}$ Some of the terms conssulted were: Residual Income Valuation; Linear Information Model; Linear Information Dynamics; Ohlson's Model; Edwards-Bell-Ohlson; EBO.
} 
future dividends being established. The stochastic process that defines the third premise is known as Linear Information Dynamics, or dynamics of linear information (DIL) and is given by the equations:

$$
\begin{gathered}
\tilde{x}_{t+1}^{a}=\omega x_{t}^{a}+v_{t}+\tilde{\varepsilon}_{1, t+1} \\
\tilde{v}_{t+1}=\gamma \mathcal{V}_{t}+\widetilde{\varepsilon}_{2, t+1}
\end{gathered}
$$

where $x_{t}^{a}$ is the abnormal profit (or residual profit) for the period " $t$ "; $v_{t}$ means "other information " about expected future residual profits that are observed at the end of period " $t$ " but were still not recognized by the accounting; $\omega$ and $\gamma$ are parameters of persistence ; $\widetilde{\varepsilon}_{1}$ and $\widetilde{\varepsilon}_{2}$ represent the terms of stochastic errors assumed for having mean zero and normal distribution.

The DIL represents the great contribution of Ohlson for the research of evaluation of companies (FUKUI, 2001). Its construction is based on the presupposition that the information about the future residual profits is obtained both from the past series of the abnormal profits and of data still not captured by the accounting (MCCRAE; NILSSON, 2001). The two dynamic equations are combined with CSR to guarantee that all the relevant events relating to the value of the company are absorbed by the profits and accountable value of the PL (OHLSON, 1995). One assumes that $x_{t}^{a}$ and $v_{t}$ follow a self regressive process of a single interval and that the parameters of persistence $-\omega$ and $\gamma$ - are both restricted for being not negative and less than 1.

As to the "Other information", Lundholm (1995) teaches that they refer to non accountable information that proportion a chock in the residual profits in future periods. Ohlson (1995) assumes that $v_{t}$ must be considered as a summary of the relevant events for the evaluation of the company that will still cause an impact on the financial statements. Based on the ALR and on equations (5) and (6), Ohlson obtains the function of evaluation:

$$
p_{t}=b_{t}+\alpha_{1} x_{t}^{a}+\alpha_{2} v_{t}
$$

where $\alpha_{1}=\frac{\omega}{(R-\omega)}$ and $\alpha_{2}=\frac{R}{(R-\omega)(R-\gamma)}$.

With these constructions Ohlson imposed an additional structure in the ALR so that the evaluation could be expressed as a function of the contemporaneous accountable data and no longer only in predictions (LEE, 1999 e LO; LYS, 2000). Differently to some traditional models (MDD and Discounted Cash Flow), the evaluation formula of Ohlson - given by equation (7) - does not require explicit forecasts of future dividends nor of additional premises of calculation of the terminal value (DECHOW et al., 1999).

Two observations related to the coefficients $\alpha_{1}$ and $\alpha_{2}$ help to understand the functionality of the model. For $\omega>0$, the two coefficients are positive simply because the predictions $E_{t}\left[\tilde{x}_{t+\tau}^{a}\right]$, for any $\tau>1$, relate positively with $x_{t}^{a}$ and $v_{t}$. The extreme case of $\omega=0$ implies that $E_{t}\left[\tilde{x}_{t+\tau}^{a}\right]$ is independent of $x_{t}^{a}$ and therefore $p_{t}$ cannot depend on $x_{t}^{a}$ (OHLSON, 1995). Additionally, the functions $\alpha_{1}(\omega)$ and $\alpha_{2}(\omega, \gamma)$ react in an increasing way to their 
arguments, that is, high values of $\omega$ and $\gamma$ make $p_{t}$ more sensitive to the realizations of $x_{t}^{a} \mathrm{e}$ $v_{t}$.

The MO still incorporates properties of Modigliani and Miller (1961), which are: (i) dividends affect the market value on the dollar-to-dollar basis, implying the premise of the irrelevance of the payment of dividends; (ii) the dividends paid in the current period would negatively influence the expected future profits. Combined, the two properties indicate that the dividends reduce the accountable value of the PL but do not influence the current profit (OHLSON, 1995).

\subsection{Entries Required}

In the determination of the parameters of the Ohlson model, some of the necessary data is promptly available whereas others must be established. Specifically, the model depends on: (i) three variables: the accountable value of the PL in the current period - $b_{t}$, profits in the current period - $x_{t}$ - and other information in the current period - $v_{t}$; (ii) three parameters: $\omega$ and $\gamma$, which are parameters of persistence, and $r$, which is the discount rate. Accounts reports - such as the Patrimonial Balance Sheet, Income Statement of the Period and Statement of Changes in the Net Worth - supply the basis for the fixing of the first two variables $\left(b_{t}\right.$ and $\left.x_{t}\right)$. The remaining variable $\left(v_{t}\right)$ and the three parameters are more difficult to be measured.

Ohlson (1995) offers little or no orientation as to how to obtain the variable $v_{t}$ and the parameters of persistence $\omega$ and $\gamma$. The task therefore remained relegated to future research. In this context diverse methodologies or proxies were suggested in academic works that tested the MO.

\subsubsection{Establishing the Discount Rate $(r)$}

In the task of evaluation it is necessary to identify a discount rate that converts flows that will be realized (or one expects they will be realized) into present values. There are various ways of measuring $r$ and the literature about the theme is extensive. Approaches include the cost of own capital, the average pondered cost of capital, the rate of return on the PL or on the asset, amongst others. The detailed discussion of each one of the possible focuses to determine the discount transcends the objective o this article. ${ }^{\mathrm{vi}}$.

The MO assumes that $r$ is defined in a non stochastic way, considering neutrality to the risk and homogenous beliefs (OHLSON, 1995, p. 665). The discount rate used in various empirical works on the Ohlson model is the rate of return of the Net Worth (DECHOW et al., 1999; FRANKEL; LEE, 1999). Martins (1998) reminds us that this procedure is a debatable point since the investors have difference opinions with respect to the minimum profitability expected for the company.

\footnotetext{
${ }^{\overline{v i}}$ Examples of some approaches (model of three factors and rate of return by industry) can be obtained in the works of Fama and French (1997, 1998).
} 


\subsubsection{Establishing Other Information $\left(v_{t}\right)$}

Kothari (2001) reminds us that the current performance of the company (such as presented in the accounts reports) is an important, but not the sole, source of information for the evaluation of the market value of the company. Dechow et al. (1999) remind us that for some time the academic literature has recognized that the share prices reflect information about future profits that are not contained in the current profits. Such information cannot be observed directly (OHLSON, 2001, p. 112). Candidates for this "other information" $\left(v_{t}\right)$ are new patents, approval of laws for a new medicament in pharmaceutical companies, long term contracts, amongst others (MYERS, 1999). Attempts to incorporate $v_{t}$ within the analysis of evaluation go back at least to the year of 1980 with the work of Beaver et al. (1980).

Ohlson (1995) defines "other information" as a scale variable, however, he does not concretely establish its analytical content. Recently the very Ohlson (2001, p. 112) referred to $v_{t}$ as a "mysterious" variable. The lack of definition of the variable "other information" caused many researchers to neglect its use in the tests on the MO (BEAVER, 1999, p. 38). As to this aspect, Hand (2001, p. 122) highlights that up to 1998 almost all empirical research on the MO disdained the informational content of $v_{t}$. The few articles that did not leave "aside" the variable "other information" chose an intuitive path instead of a formal construction (examples include AMIR and LEV, 1996 apud HAND, 2001 and MYERS, 1999).

Ohlson (2001) sustains that although there may be an analytical interest in not specifying the value of $v_{t}$, such procedure reduces the empirical content of the MO. He also highlights that consensual forecasts of analysts constitute a reasonable tool to measure the expected future profits and that there is no reasons to eliminate $v_{t}$ from the model since the variable can be based on observable data ${ }^{\mathrm{vii}}$. Hand (2001) adds that to consider $v_{t}$ equal to zero is to make the "heroic" assertive that the accounts data publicly available are sufficient to explain the share prices.

\subsubsection{Establishing the parameters of Persistence ( $\omega$ and $\gamma$ )}

The linear dynamics presented by Ohlson (1995) define the relationship between current and future information using a self regressive process of the first order - AR (1). The residual profit of the following period $\left(x_{t+1}^{a}\right)$ is a function of the residual profit of the current period (adjusted by a coefficient of correction denominated parameter of persistence), other information $\left(v_{t}\right)$ and a term of error $\left(\varepsilon_{1, t+1}\right)$. In turn, other information of the following period $\left(v_{t+1}\right)$ is a function of other information of the current period (also adjusted by a coefficient of correction) and a term of error $\left(\varepsilon_{2, t+1}\right)$. The parameter of persistence of residual profits is indicated by the notation $\omega$ and $\gamma$ and the parameter of persistence of other information.

Ohlson does not establish criteria to obtain $\omega$ or $\gamma$, restricting himself to declaring that the economic medium and the accounts principles of the company determine the exogenous parameters $\omega$ and $\gamma$ (OHLSON, 1995, p. 686). Also institutes that such parameters must not be negative or greater than 1 (one). Such parameters are directly used in the determination of the coefficients of the function of evaluation proposed by Ohlson (1995),

\footnotetext{
${ }^{\overline{v i i}}$ Forecasts of analysts for example.
} 
as seen in equation (7). The coefficient $\alpha_{1}$ is a function of $\omega$ and $\alpha_{2}$ is a function of $\omega$ and $\gamma$.

In a recent article that addresses the empirical perspective of its model, Ohlson (2001, p. 115) declares that researchers must try to estimate the value of $\omega$ and $\gamma$, without indicating how this could or should be done. The work of Dechow et al. (1999) is referenced by Ohlson as one of the empirical studies of the MO that evaluates the attributes of the model in a closer way (OHLSON, 2001, p. 108). In the establishing of the parameters of persistence, Dechow et al. $(1999$, p. 7) consider the historical sample estimates of $\omega$ and $\gamma$.

\subsubsection{Establishing the Variables $b_{t}$ and $x_{t}$}

Ohlson (1995) uses well known concepts obtained from accounts reports such as the profit $\left(x_{t}\right)$ and the value of the net worth $\left(b_{t}\right)$. However, for use of the variables $x_{t}$ and $b_{t}$, the MO imposes a restriction of the relationship Clean Surplus (CSR) ${ }^{\text {viii }}$, that has direct reflex on the quality of the accounts data.

\subsubsection{Source of Data}

Implications of regulatory nature determine at times the requirement of publication of accounts statements ${ }^{\text {ix }}$. Companies and specialized periodicals disclose information about the macroeconomic environment and rates of return, amongst other data of interest. Information providers keep current and historical data as well as forecasts of companies and of market segments.

The availability of computational data bases (relating to the financial information of the companies) stimulated rapid growth in accounting research in the capital market (BROWN, 2001). The United States of America (USA) was pioneer in the construction of these types of data bases (BROWN, 2001). In foreign literature ${ }^{\mathrm{x}}$, one sees the frequent use of the following sources of data ${ }^{x i}$ :

1. Forecast of Profits: In the USA there are various entities that undertake to provide the estimate of future profits of companies. Value Line has published its estimates since the decade of the 70's. Standard \& Poor's has published its forecasts weekly from 1967 to 1987, in a bulletin called Earnings Forecaster. Other companies that make forecasts of profits are: Institutional Brokers Estimate System (I/B/E/S), originally published by Lynch, Jones and Ryan, and Zacks Investment Research (The Icarus Service).

2. Accounts and Financial Data: COMPUSTAT offers historical data (from 1987) of approximately 22,000 companies headquartered in the USA (active or not). Now the Center for Research in Security Prices (CRSP) is a center of financial research of the University of

\footnotetext{
viii Described in equation (4).

${ }^{\text {ix }}$ In Brazil in the case of limited liability corporations of open capital, this requirement can be conferred in art. 289 of Law 6.404/76 and with the new wording given by Law $n^{\circ}$ 9.457, of 5.5.1997, which sets forth thus: "The publications ordered by the present Law will be done in the official organ of the Union or the State of the Federal District, according to the place in which the head office of the company is situated, and in another neewspaper of large circulation published in the place in which the head office of the company is situated ".

${ }^{x}$ Particularly North American

${ }^{x i}$ All the providers cited are companies headquartered in the USA.
} 
Chicago that has a data bank of the share market (prices, indexes etc) of companies negotiated in the principal North American Stock Exchanges (NASDAQ, AMEX, NYSE).

\subsection{Hypothetical example}

The example was developed in the attempt to reproduce an application of the Ohlson model. It should be highlighted that the data and the environment imagined are hypothetical and therefore subject to the limitations inherent to the specifications of this species. One sought to privilege the didactic aspect in detriment to a more rigorous specification (greater horizons of forecast and of the temporal series of profits and net worth, inclusion of forecast of the administration etc).

The scenario where the illations are developed, part of the existence of a metallurgical company, Carol Inc., that has been participating in the industry of metals and laminates for 20 years. An efficient market is admitted in semi-strong form. For the segment of activities an average rate of return on own capital of $7 \%$ was seen. Additionally, the following information is supplied in TABLE 1 :

\section{TABLE 1}

Available date of Carol Inc.

\begin{tabular}{|c|c|c|c|c|c|}
\hline & & & & poral & \\
\hline & $t-5$ & $t-4$ & $t-3$ & $t-2$ & $t-1$ \\
\hline Profits & 10.0 & 10.1 & 10.3 & 10.5 & 10.7 \\
\hline Dividends & 6.0 & 6.0 & 6.0 & 6.0 & 6.0 \\
\hline $\begin{array}{l}\text { Forecast of profit* } \\
\text { Note: } \\
\text { * The forecasts of }\end{array}$ & $\begin{array}{l}8.3 \\
\text { onser }\end{array}$ & 8.4 & 8.5 & 8.5 & 8,6 \\
\hline
\end{tabular}


The net worth of the company was $\$ 100$ in the period $t-6$. Taking the existent information as basis one can obtain the results shown in TABLE 2:

\section{TABLE 2}

Calculated Data of Carol Inc.

Net Worth*

$\left(b_{t}=b_{t-1}+x_{t}-d_{t}\right)$

Normal Profit**

$\left(x_{t}^{\prime}=b_{t} \times 0,07\right)$

Residual Profit

$\left(x_{t}^{a}=x_{t}-x_{t}^{\prime}\right)$

Persistence Residual

Profits***

$\left(\delta=x_{t}^{a} \div x_{t-1}^{a}\right)$

Error of Forecast $* * * *$

(Forecast - Observed) /

Observed

Return on PL (ROE)

$\left(R O E=x_{t} \div b_{t}\right)$

ROE Residual*****

$\left(R O E^{r e s}=R O E-r\right)$

Dividend Payment Rate $(k)$

$\left(k=d_{t} \div x_{t}\right)$
Temporal Series

$\frac{t-5}{104.0} \frac{\boldsymbol{t}-\mathbf{4}}{108.1} \frac{\boldsymbol{t}-3}{112.3} \frac{\boldsymbol{t}-2}{116.8} \frac{\boldsymbol{t}-\mathbf{1}}{121.5}$

6.00

6.24

6.49

6.74

7.01

4.00

3.86

3.76

3.76

3.69

0.97

0.98

1.00

0.98

$-0.18$

$-0.17$

$-0.17$

$-0.19$

$-0.20$

0.10

0.09

0.09

0.09

0.09

0.04

0.03

0.03

0.03

0.03

0.60

0.59

0.59

0.57

0.56

\section{Notes:}

* Calculated in accordance with the relationship Clean Surplus - see equation (4).

** The notation $x_{t}^{\prime}$ was used for normal profit.

*** The notation $\delta$ was used for the persistence in residual profits.

**** Calculated in accordance with the methodology suggested by Francis et al. (2000).

***** ROE residual was defined as $R O E^{\text {res }}$ and the discount rate as " $r$ ".

The historical series of TABLE 2 was used for the calculation of the parameter of persistence $\omega$. One sees the existence of residual profits in all the periods and their persistence, on average, was approximately $98 \%$ in relation to the immediately previous period.

In period $t$, the company promoted the implantation of a new boiler apart from a training program for the reduction of the waste matter of production, and work accidents. The administration is confident that such actions will have positive repercussion in the 
productivity of the company. Based on this information the analysts forecast an additional result of \$2 per period in Carol Inc. However, it is known that the information of the analysts has a bias (mean) to below $-18 \%$. The variable $v_{t}$ was calculated as being $\$ 2.36$ and the parameter of persistence $\gamma$ equal to one.

The calculation of the coefficients of the formula of evaluation - equation (7) returned a value of 10.89 for $\alpha_{1}$ and 169.84 for $\alpha_{2}$. By the formula the value of the company would be $\$ 562.5$ :

$$
\begin{aligned}
& p_{t}=121,5+(10,89 \times 3,69)+(169,84 \times 2,36) \\
& p_{t}=562,5
\end{aligned}
$$

The example offers a notion of how the parameters and variables involved in the Ohlson modeling interact. The formula of evaluation returned the intrinsic value ${ }^{\mathrm{xii}}$ of the company by the Ohlson model (1995). The comparison of this with the respective market value would be the next step to identify the degree of response offered by the MO for the scenario imagined $^{\text {xiii }}$.

\subsection{Extensions of the Model}

Researchers have gone deep into the theoretical study of the MO, with the aim of offering a more consistent basis or to propose modifications in the underlying theory of the Ohlson model. Examples include the treatment of Dirty Surplus items in the model of evaluation (LO; LYS, 2000); the inclusion of more periods in the self regressive process (OTA, 2000); the incorporation of a stochastic rate of interest and aversion to risk (ANG; LIU, 1998); the structuring of a non linear informational dynamic (BIDDLE et al., 2000) etc.

Of the work related to the theory of the MO, those elaborated by the very Prof. James Ohlson, individually or in partnership with other researchers, are highlighted.

- Conservatism, Operational Assets and Growth of the PL: concomitant with the publication of the article that established the structuring of the MO, James Ohlson offered an extension of his model, conceived jointly with Prof. Gerald Feltham. Up to the moment the work of Feltham and Ohlson (1995) represents the most notorious extension of the MO and sometimes is referenced as if it were him (LOPES, 2001). The Feltham-Ohlson model (1995) - MFO - provides a differenced treatment of financial and operational assets for the purposes of evaluation. This separation is done due to the fact that the accountancy for the historical cost differs systematically from the fair value. The dynamic information of the MFO differ from those instituted in the MO, highlighting the inclusion of a coefficient that measures the degree of conservatism of the accountancy and another that defines the parameter of growth of the accountable value of the PL. To reduce the bias contained in the

\footnotetext{
xii According to Myers (1999), "intrinsic value is equal to the present value of the expected future dividends indiferently to the policy of payment of dividends or the quality of the accountable numbers as long as the relationship Clean Surplus is observed ”. (our translation and highlighting)

${ }^{\text {xiii }}$ Myers (1999) suggests the use of the market value as benchmark for the intrinsic value of the company. In the example, obviously, the degree of response of the Ohlson model to the value of the company (by the market) cannot be identified since it is a question of a hypothetical company.
} 
accountable profit ${ }^{\mathrm{xiv}}$, MFO assumes the premise that the residual profits for financial assets will always be equal to zero. Thus one can simplify the model to focus exclusively on the operational assets. The simplification done, no modification is required for MDD, CSR or ALR. The informational dynamics of the MFO are different than the MO. Whereas this latter counts on only two $\mathrm{DIL}^{\mathrm{xv}}$, the MFO establishes four;

- Transitory Profits: Ohlson (1999) makes an analysis of the concept of transitory profits, their impact on the evaluation of the company using the ALR and their difference in relation to the other items of profits. He argues that the accounts theory and analysts of accounts reports recognize that some sources of profits can be characterized as transitory and that they need to be separated or eliminated from the income statement of the period. The informational dynamics and the formula of evaluation were modified to include transitory profits, proportioning a way of dealing with this species of profit to estimate the value of the companies;

- Stochastic Interest Rate: the underlying theory of the Ohlson model simplified the role of the risk in the function of evaluation, assuming that the investors are neutral to the risk and interest rates are fixed and non stochastic. Recently, Feltham and Ohlson (1999) demonstrated analytically that it is possible to incorporate the risk both in the MO and in the MFO. The procedure consists of substituting expected future residual profits for equivalent certainties based on the aversion to the risk by the investor between the date and possible events. The pricing of the risk will depend on the appropriate set of information referent to the events and possible dates of the future residual profits, to obtain the equivalent certainties. The study of Feltham and Ohlson (1999), however, is silent in the demonstration of how the investors and researchers can obtain this set of information. The work of Gode and Ohlson (2000) also generalizes the MO to include stochastic interest rates basing itself on the fact that the changes in the interest rates are relevant because they modify perceptions of the long term profits. The most recent study (identified) on the application of the risk in the model of Ohlson is of Baginski and Wahlen (2003).

- Depreciation: Feltham and Ohlson (1996) examined the impact of the policy of depreciation of the company in the relationship between the accounts numbers and the market value of the company. At the start of the discussions the authors warn that the policy of depreciation affects the accountable numbers but does not have effect on the market value of the company. Specifically, whereas the accounting policy must affect the representation of the information received by the investors, Feltham and Ohlson (1996) assume that it does not affect the information relevant value received. The study identified policies of depreciation that provide unbiased or conservative accounting, that is, the goodwill not registered is equal or exceeds "zero" on average respectively. It was also demonstrated that the economic profits are equal (on average) to the accountable profits if the accountancy is not biased or if there is no increase in the value of the PL.

\footnotetext{
${ }^{\overline{x i v}}$ Resulting from the delay in the recognition of economic events by the accountancy.

${ }^{\mathrm{xv}}$ See equations (5) and (6).
} 


\section{CONCLUSIONS}

This work proposes to analyze the Ohlson model being that the task consisted of identifying the origin of the model, raising the underlying theory, verifying the entries demanded, to structure a hypothetical example to demonstrate the logic involved in the internal consistency of the linear informational dynamics and finally to identify the state of the art.. During this course diverse points were identified and debated. Part of them is found presented ahead under the title of ascertainments:

1. There is no consensus in the academic literature about the appropriate method to measure the parameters of persistence ( $\omega$ and $\gamma$ ).

2. There are propositions of improving the original conception of the MO by means of extensions to the model. The approach of the conservatism, growth, risk and transitory profits already constituted the list of studies that focalize on the theory relating to the Ohlson model.

3. The Ohlson model propitiated a series of contributions in the academic literature about capital markets: relit the debate around the evaluation by residual profits in the research of evaluation; gave support so that the accounts numbers could be used in models of evaluation; adopted a more desirable focus on the distribution of wealth for an orientation directed to the creation of value for the company; intensified the interest in studies of value relevance that connect accounting variables (accountable value of the PL and profits, principally) the models of evaluation of companies and orientated opportunities for future research as for example studies that focalize variables and parameters of the Ohlson model.

\section{REFERENCES}

ANG, A.; LIU, J. A Generalized Earnings Model of Stock Valuation. Working Paper, Stanford University, 1998.

BAGINSKI, S. P.; WAHLEN, J. M. Residual Income Risk, Intrinsic Values, and Share Prices. The Accounting Review, v. 78, n. 1, p. 327-351, 2003.

BEAVER, W. H. Comments on "An Empirical Assessment of the Residual Income Valuation Model". Journal of Accounting and Economics, v. 26, p. 35-42, 1999.

BEAVER, W; LAMBERT, R.; MORSE, D. The Information Content of Security Prices: a Second Look. Journal of Accounting and Economics, v. 2, p. 3-28, 1980.

BEUREN, I. M. (Org.). How to Prepare Monographic Work in Accountancy: Theory and Practice. São Paulo: Atlas, 2003.

BIDDLE, G. C.; CHEN, P; ZHANG, G. When Capital Follows Profitability: Non-linear Residual Income Dynamics. [S.1.]: Social Science Research Network, 2000. Available at: $<$ http://papers.ssrn.com/sol3/papers.cfm?abstract_id=251188>. Access on 01 Nov. 2002, 23:59:07.

BODIE, Z.; MERTON, R. C. Finaness. 1. ed. rev. ampl. Porto Alegre: Bookman Editora, 2002.

BROWN, P. Capital Markets-Based Research in Accounting: An Introduction. [S.1.]: The University of Western Australia, 2001. Available at:

<http://www.lums2.lancs.ac.uk/ACFIN/Staff/PBrown.htm>. Access on 01 Feb. 2003, 15:22:07.

CERVO, A. L.; BERVIAN, P. A. Scientific Methodology: For the Use of University Students. São Paulo: McGraw-Hill do Brasil, 1983.

DAMODARAN, A. Evaluation of Investments: tools and techniques for the determining of the value of any asset. Rio de Janeiro: Qualitymark, 1999. 
DECHOW, P. M.; HUTTON A. P.; SLOAN R. G. An Empirical Assessment of the Residual Income Valuation Model. Journal of Accounting and Economics, v. 26, p. 1-34, 1999. FELTHAM, G. A.; OHLSON , J. A.. Valuation and Clean Surplus Accounting for Operating and Financial Activities. Contemporary Accounting Research, v. 11, p. 689-731, 1995. Uncertainty Resolution and the Theory of Depreciation Measurement.

Journal of Accounting Research, v. 34, n. 2, p. 209-234, 1996. . Residual Earnings Valuation with Risk and Stochastic Interest Rates. The Accounting Review, v. 74, p. 165-183, 1999.

FERNÁNDEZ, P. Company Valuation Methods: The Most Common Errors in Valuations. [S.1.]: Social Science Research Network, 2001. Available at: 〈http://papers.ssrn.com>. Access on 19 Oct. 2003.

FRANKEL, R.; LEE, C. M. C. Accounting Valuation, Market Expectations, and CrossSectional Stock Returns. Journal of Accounting Economics, v. 25, p. 283-319, 1998. FUKUI, Y. A Data Admissible Ohlson Model. [S.1.]: Social Science Research Network, 2001. Available at: <http://papers.ssrn.com/sol3/papers.cfm?abstract_id=289039>. Access on 11 Dec. 2002, 17:50:27.

GODE, D.; OHLSON, J. A. Valuation, Linear Information Dynamic, and Stochastic Discount Rates. [S.1.]: Social Science Research Network, 2000. Available at: $<$ http://papers.ssrn.com>. Access on 10 Mar. 2003, 12:17:12.

HAND, J. R. Discussion of Earnings, Book Values, and Dividends in Equity Valuation: An Empirical Perspective. Contemporary Accounting Research, v. 18, n. 1, p. 121-30, 2001. HOPPEN, N.; LAPOINTE, L.; MOREAU, E. A Guide for Evaluation of Articles of Research in Information systems, [S.1.]: Administration electronic magazine, 1996. Available at: <http://read.adm.ufrgs.br/read03/read03.htm>. Access on 14 Mar. 2003, 10:37:12.

KOTHARI, S. P. Capital Markets Research in Accounting. Journal of Accounting and Economics, v. 31, p. 105-231, 2001.

LEE, C. M. C. Accounting-Based Valuation: impact on business practices and research. Accounting horizons, v. 13 (4), p. 413-425, 1999.

LO, K.; LYS, T. The Ohlson model: contribution to valuation theory, limitations, and empirical applications. Journal of Accounting, Auditing and Finance, v. 15, (Summer), p. 337-67, 2000.

LOPES, A. B. The Relevance of Accounting Information for the Capital Market: the Ohlson model applied to Bovespa. 1v. 308p. Thesis (Doctorate in Controllership and Accounting). University of São Paulo, 2001.

LUNDHOLM, R. J. A Tutorial on the Ohlson and Feltham/Ohlson Models: Answers to some Frequently Asked Questions. Contemporary Accounting Research, v. 11, p. 749-761, 1995. MARTINS, E. Evaluating the Company (I). IOB: Thematic and Accounting and Balance Sheets Book, n. 10, $1^{\text {st }}$ Week Mar., p. 1-6, 1998.

MCCRAE, M.; NILSSON, H. The Explanatory and Predictive Power of Different Specifications of the Ohlson (1995) Valuation Models. The European Accounting Review, v. 10, n. 2, p. 315-341, 2001.

MODIGLIANI, F.; MILLER, M. H. Dividend Policy, Growth, and the valuation of shares. The Journal of business, v. 34, n. 4, p. 411-433, 1961.

MYERS, J. N. Implementing Residual Income Valuation with Linear Information Dynamics. The Accounting Review, v. 74, p. 1-28, 1999.

OHLSON, J. A. Earnings, Book Values, and Dividends in Equity Valuation. Contemporary Accounting Research, v. 11, p. 661-687, 1995. On Transitory Earnings. Review of Accounting Studies, v. 4, p. 145-162, 1999. 
Earnings, Book Values, and Dividends in Equity Valuation: An Empirical

Perspective. Contemporary Accounting Research, v. 18, p. 107-120, 2001.

OTA, K. A New Improvement to the Ohlson (1995) Model: Empirical Evidence from

Japan. [S.1.]: Social Science Research Network, 2000. Available at: <http://papers.ssrn.com>. Access on 03 Mar. 2003, 23:45:15.

PENMAN, S. H.; SOUGIANNIS, T. A Comparison of Dividend, Cash Flow, and Earnings Approaches to Equity Valuation. Contemporary Accounting Research, v. 15, n. 3, fall, p. 343-383, 1998.

PLENBORG, T. Firm Valuation: Comparing the residual income and discounted cash flow approaches. [S.1.]: Social Science Research Network, 2000. Available at:

$<$ http://papers.ssrn.com>. Access on 30 Oct. 2002, 08:54:20.

RICHARDSON, R. J. Social Research: Methods and Techniques. 3 ed. São Paulo: Atlas, 1999. 